University of Nebraska - Lincoln

DigitalCommons@University of Nebraska - Lincoln

Sociology Department, Faculty Publications

Sociology, Department of

October 1990

\title{
Media Stereotyping: A Comparison of the Way Elderly Women and Men Are Portrayed on Prime-Time Television
}

JoEtta A. Vernon

University of Nebraska-Lincoln

J. Allen Williams Jr.

University of Nebraska-Lincoln, jwilliams2@unl.edu

Terri Phillips

University of Nebraska-Lincoln

Janet Wilson

University of Nebraska-Lincoln

Follow this and additional works at: https://digitalcommons.unl.edu/sociologyfacpub

Part of the Sociology Commons

Vernon, JoEtta A.; Williams, J. Allen Jr.; Phillips, Terri; and Wilson, Janet, "Media Stereotyping: A Comparison of the Way Elderly Women and Men Are Portrayed on Prime-Time Television" (1990). Sociology Department, Faculty Publications. 5.

https://digitalcommons.unl.edu/sociologyfacpub/5

This Article is brought to you for free and open access by the Sociology, Department of at DigitalCommons@University of Nebraska - Lincoln. It has been accepted for inclusion in Sociology Department, Faculty Publications by an authorized administrator of DigitalCommons@University of Nebraska - Lincoln. 


\title{
Media Stereotyping: A Comparison of the Way Elderly Women and Men Are Portrayed on Prime-Time Television
}

\author{
JoEtta A. Vernon, RN, MS \\ J. Allen Williams, Jr., PhD \\ Terri Phillips, MA \\ Janet Wilson, MS
}

\begin{abstract}
This content analysis of 139 programs and 2,211 characters updates and extends previous research on the way elderly people, and especially elderly women, are presented on prime-time television. Findings indicate that females and the elderly continue to be significantly underrepresented. Comparisons of elderly men and women showed patterns of traditional stereotypes, with men more likely to be depicted positively on 7 of 9 desirable traits and women more likely to be depicted negatively on 6 of the 7 undesirable traits which showed a gender difference. However, the proportional differences for specific characteristics typically were neither large nor statistically significant, suggesting that there has been some change in television's portrayal of the elderly during the $1980 \mathrm{~s}$. It also was noted that television appears to be more accepting and open to the portrayal of older middle-aged men than women in the same age category.
\end{abstract}

JoEtta A. Vernon is a doctoral candidate at the University of Nebraska-Lincoln where she is specializing in the areas of aging and the life course and the sociology of the family. J. Allen Williams, Jr. is Professor of Sociology at the University of Nebraska-Lincoln. His major research areas are the sociology of the family, minorities, and environmental sociology. Terri Phillips and Janet Wilson are doctoral candidates at the University of Nebraska-Lincoln. Phillips is specializing in social psychology and deviance and criminology and Wilson is specializing in deviance and criminology and sex and gender.

Journal of Women \& Aging, Vol. 2(4) 1990

(C) 1991 by The Haworth Press, Inc. All rights reserved. 
Past research findings related to images of the elderly and women have three dominant themes: first, older people and females are presented in disproportionately small numbers; second, the reality of their lives tends to be distorted; and, third, older women tend to be depicted less favorably than older men (for example, Peterson, 1973; Aronoff, 1974; Northcott, 1975; Carmichael, 1976; Signorielli and Gerbner, 1978; Greenburg, Korzenny and Atkin, 1979; Tibbitts, 1979; Gerbner, Gross, Signorielli, and Morgan, 1980).

Television's portrayal of the elderly, especially during the primetime hours, has received little attention for over a decade. Among the studies that have been done, most have focused on daytime television and/or programing watched primarily by children (for example, Cassata, Anderson and Skill, 1980; Elliot, 1984; Holtzman and Akiyama, 1985). The one study, Dail (1988), that recently looked at prime-time television and the elderly included only family-oriented programing ( 30 hours) and concluded that more systematic research is needed. However, Dail (1988) does suggest that the portrayal of the elderly may be improving.

Clearly, events such as the increasing proportion of women in the labor force and the women's movement for equal rights should have helped to diminish sexism during the 1980s (Senter, 1982; Bergman, 1986). While there is ample evidence of ageism in American society, it also is true that the population is growing older and that older citizens are becoming more vocal with respect to their treatment and rights (Austin, 1985). Furthermore, Tibbits (1979) proposed that a change has been taking place regarding the views of aging and older people in general. His thesis is that American society has been transforming itself from one in which older people were characterized by negative stereotypes to "one in which the roles and styles of life of older adults will be viewed as positive and contributive to the quality of life for themselves, for their communities, and for the total society" (Tibbits, 1979, p. 10).

If American society is indeed becoming more positive toward the elderly and more egalitarian with respect to gender, it is reasonable to propose that these changes will be reflected in the popular media. That persons involved with determining media content are aware of sentiments against sexist and ageist material is certain. According to Kubey (1980), the American television industry began an effort to eliminate negative images of ethnic minorities and women in the 
late 1960s and extended this to encompass age ten years later. The present study addresses the question of whether there in fact has

- been a change in the way the elderly, and especially elderly women, are presented on prime-time television.

\section{TELEVISION AND THE ELDERLY}

With few exceptions, social scientists posit that the content of television programs provides both a reflection of, and an influence on, society's view of the elderly (Gerbner et al., 1980; Davis and Davis, 1985). ${ }^{1}$ Davis and Davis (1985) suggest that television is a mediated or secondary experience, but it also is a major source of ideas about life. However, the process by which television influences its viewers is complex and differs by age group. Greenburg et al. (1979) contend that the influence of commercial television may be of particular importance for two viewing groups - children and the aged. Television viewing decreases as children grow older, but increases once again among older persons. Comstock, Chaffee, Katzman, McCombs and Roberts (1978) found that watching television is the predominant leisure time activity for people over 65 years of age. Older viewers may derive implications for their own self-image and expectations about the realities of old age. For young viewers, television may be a primary source on how old age and older persons are perceived. Davis and Davis (1985) point out that age-segregated housing, dispersed families, and other social conditions tend to separate today's children from the realities of growing old. In addition, Gerbner et al. (1980) report that the more people, especially young people, watched television, the more they perceived old people in unfavorable terms. Gerbner et al. (1980) propose that since children are more "distant" from old age, they are more vulnerable to television's messages.

All previous content analyses of the portrayal of older people on television have found an underrepresentation when compared to their numbers in the general population. Aronoff (1974), for example, found that the elderly comprised less than 5 percent of television characters shown during prime time, although they made up 12 percent of the American population. Greenburg et al. (1979), using data collected from 1975 to 1977 , found a decline during primetime from 4 percent in 1975 to 2 percent in 1977. Studies that have 
focused on daytime broadcasting have found a higher percentage of the elderly, but, again, not in proportion to their actual numbers in the population (see Harris and Feinberg, 1977; Ansello, 1978; Cassata et al., 1980; Elliot, 1984). With respect to cartoons, programming watched almost exclusively by children, Bishop and Krause (1984) report that old age was seldom addressed in the 106 cartoons they observed over a six-week period.

It appears that gender interacts with age in that studies have found that older women fare less well than older men; they are seen less often and have less productive roles when they do appear. Peterson (1973) found that a viewer could expect to see an old man on prime-time television every 22 minutes and an old woman only every four or five hours. Aronoff (1974) noted that the average age of female television characters was about ten years younger than males. In the same vein, studies by Downs and Harrison (1985) and Silverstein, Perdue, Peterson, and Kelly (1986) found that television promotes the message that females should be young as well as thin and attractive.

Research also indicates that the elderly, regardless of gender, tend to be negatively stereotyped. Aronoff (1974) found that aging is associated with evil, failure, and unhappiness. Carmichael (1976) reports that his research found older people being portrayed as ugly, senile, and ill. Additionally, research indicates that older characters usually play parts peripheral to the main story plot (Ansello, 1978; Cassata et al., 1980; Elliot, 1984). Harris and Feinberg (1977) refer to the roles allocated to the elderly as "remarkably one-dimensional." This point is reiterated by Kubey (1980), who concludes that the elderly are typically portrayed as one-dimensional figures, often with either negative characterization or "reversed stereotyping," e.g., older people who are extremely active physically or sexually.

\section{METHODS}

The four investigators independently coded the prime-time programming of three commercial television networks; $\mathrm{ABC}, \mathrm{NBC}$, and CBS. Each network's offerings from 7:00 p.m. to 10:00 p.m. were viewed for one week in fall, 1987 and one week in summer, 1988. The initial study consisted of three weeks of viewing during 
fall, 1987 and was coded by two investigators making independent evaluations. Although inter-coder reliability was quite high, it was decided to increase both the number of coders and television shows. Thus, four coders independently evaluated shows during the summer of 1988. A comparison of the fall and summer findings shows no significant differences with respect to the variables measured in this study. A total of 139 programs were watched. Sports events and "specials" were excluded. Only characters with speaking parts (one or more words) were included, yielding a total of 2,211 characters.

For each program, coders noted the number of characters and the approximate age and gender of each. Persons 65 years of age and older were considered elderly for this study. Determinations were made on the basis of physical characteristics and/or by role definition. Criteria for classifying an individual as elderly were adopted from Elliot (1984) and included role as great-grandparent, parent of a child age 45 or older, character self-described as older or treated as elderly in the dialogue. Other age categories were 40 to 64 (middle-age) and 39 and younger (young).

To measure possible stereotyping of the elderly, those perceived to be age 65 and above were evaluated with respect to eighteen characteristics, nine generally regarded in American society as desirable or positive and nine regarded as undesirable or negative. These categories were selected from a summary of aged stereotypes developed by Butler (1975) and Harris (1975). Using detailed operational definitions, the four coders independently determined the presence of a characteristic within the context in which it was presented (Berg, 1989).

Intercoder reliability was 86.0 percent. However, all programs were taped so that the judges could review the material again if there was a discrepancy in coding. Consequently, near consensus on age and categorization of attributes was reached.

\section{FINDINGS}

The first question was whether females and elderly persons continue to be underrepresented in prime-time television presentations. Females make up about 51.3 percent of the United States population, whereas only 31.7 percent of the 2,211 television characters 
were classified as female. Clearly, females are underrepresented on television during these hours and this is unlikely to be a chance occurrence $(\mathrm{P}<.001$ using a test of the significance of difference between proportions). Approximately 12.1 percent of the people in the United States population are 65 years old and older, but only 3.3 percent of the television characters were classified as elderly. The difference is significant $(\mathrm{P}<.001)$ and indicates that older people continue to be underrepresented compared to their actual numbers in American society.

Our next question was whether elderly females are underrepresented compared to elderly males. As can be seen from Table 1, compared to their age-specific populations in the United States, females on television are significantly underrepresented in all age categories, and especially so among the middle-aged and elderly, with differences of 28.9 and 26.6 percent, respectively. With regards to what the television viewer observes, the male to female ratio of characters presented on television provides a useful summary. Among those characters 39 and younger, the ratio is 1.86 males to every female. The ratio is much larger among the middle-aged with 3.35 male characters appearing for each female character. The ratio decreases for the elderly to 2.04 elderly males per elderly female.

Having established that the elderly and females continue to be underrepresented on prime-time television, the analysis turned to an examination of how those who do appear are portrayed. The research question was whether the elderly continue to be presented in a distorted, negative manner. Table 2 provides the percentages of males and females who were classified according to nine attributes typically considered desirable and nine generally thought to be undesirable. It can be seen that these characteristics represent opposite ends of the same continuum, e.g., active-passive, wealthy-poor. However, if a characteristic was not appropriate for an individual, he/she was not automatically categorized as having its opposite. For example, a person was not necessarily considered to be passive just because he/she was not perceived to be active. An attribute was assigned to an individual only if it was clearly evident and a salient aspect of the individual's demeanor, personality or status.

Ideally, determination of whether the elderly are being presented in a distorted, negative manner would be based on a comparison of the distribution of characteristics in the elderly population in the 
TABLE I

Distributions of Females by Age for the United States

and Prime-rime Television

\begin{tabular}{|c|c|c|c|c|}
\hline & Age & $\begin{array}{l}\text { United states } \\
\text { Distribution } \\
\text { Percent Female }\end{array}$ & $\begin{array}{l}\text { Television } \\
\text { Distribution } \\
\text { Percent Female }\end{array}$ & $\begin{array}{l}\text { Percent } \\
\text { Difference }\end{array}$ \\
\hline 39 & and younger & 49.5 & 35.0 & $-14.5^{* * t}$ \\
\hline 40 & -64 & 51.9 & 23.0 & $-28 \cdot 9^{* * *}$ \\
\hline 65 & and older & 59.5 & 32.9 & $-26.6^{* * \hbar}$ \\
\hline
\end{tabular}

'Source: U.S. Department of Commerce, statistical Abstract of the United states. Washington, D.C.: U.S. Government Printing office. Figures for 1986 .

${ }^{2} * *=$ statistically significant at the .001 level. 


\section{(Figures Given in Percents)}

$\frac{\text { Total }}{(\mathrm{N}=64)} \quad \begin{aligned} & \text { Males } \\ & (\mathrm{N}=42)\end{aligned} \quad \frac{\text { Females }}{(\mathrm{N}=22)} \quad \begin{aligned} & \text { Male-Female } \\ & \text { Difference }\end{aligned}$

Desirable Characteritics

Active

Attractive

Creative

Flexible

Healthy

High intelligence

pleasant

Socially involved

wealthy

$\begin{array}{rrrr}50.0 & 57.1 & 36.4 & 20.7 \\ 10.9 & 7.1 & 18.2 & -11.1 \\ 4.7 & 7.1 & 0.0 & 7.1 \\ 4.7 & 7.1 & 0.0 & 7.1 \\ 12.5 & 14.3 & 9.1 & 5.2 \\ 23.4 & 23.8 & 22.7 & 1.1 \\ 26.4 & 26.2 & 27.3 & -1.1 \\ 32.8 & 35.7 & 27.3 & 8.4 \\ 20.3 & 21.4 & 18.2 & 3.2\end{array}$

Undesirable Characteristics

Passive
Ugly
Unimaginative
Rigid
Sickly
Low intelligence
Unpleasant
Socially isolated
Poor

Passive

Unimaginative

Rigid

Unpleasant

Poor

$\begin{array}{rr}4.7 & 0.0 \\ 0.0 & 0.0 \\ 0.0 & 0.0 \\ 17.2 & 14.3 \\ 6.2 & 7.1 \\ 12.5 & 9.5 \\ 14.1 & 9.5 \\ 7.8 & 4.8 \\ 4.7 & 2.4\end{array}$

13.6

0.0

0.0

22.7

4.5

18.2

22.7

13.6

9.1

$-13.6$

0.0

0.0

$-8.4$

2.6

$-8.7$

$-13.2$

$-8.8$

$-6.7$ 
society with their distribution in the television population. However, societal distributions are unknown. Nevertheless, we can examine the magnitudes of the appearance of these characteristics and we can compare the emphasis given to those perceived as desirable and undesirable. Following this procedure, the findings suggest that the elderly are not generally portrayed in a negative light. The desirable characteristics were found to apply more often than the undesirable or negative ones. Half of the elderly were shown as active, for example, while only 4.7 percent were depicted as passive. Rigidity, the most frequently assigned negative trait, was found to apply in only 17.2 percent of the cases.

It is important to mention that, while the proportion of time given to elderly characters was not measured, the investigators did note that their appearances tended to be brief and incidental to the main plot. There were only two situations that included an older person in the lead role, the movie Conspiracy of Love and the lead program J. J. Starbuck. Given the aforementioned underrepresentation of the elderly and the peripheral roles they generally play when they do appear, our judgment is that the elderly are not so much treated negatively as they are simply ignored or presented in brief, neutral and insubstantial parts.

The final research question was whether older women tend to be presented more negatively than older men. Looking first at the desirable traits by gender presented in Table 2, it can be seen that the pattern is somewhat consistent with traditional gender-role expectations with men having higher percentages who were active, creative, flexible, healthy, highly intelligent, socially involved, and wealthy. Women have higher percentages judged to be attractive and pleasant. Using a sign test, the probability of males having a larger percentage on 7 of the 9 characteristics is statistically significant using an alpha of .05. It should be emphasized, however, that the differences are small and analysis yielded no statistically significant differences between males and females on any specific characteristic.

The pattern of differences for the undesirable characteristics also is clearly consistent with traditional gender-role expectations and images of women. None of the specific differences are statistically significant, but the percentages of females judged as having an un- 
desirable attribute exceed the percentages for males on six of the seven characteristics which show a difference. Using a sign test, this pattern also is statistically significant at the .05 level.

Looking at the magnitude of having an undesirable characteristic, more than a fifth of the women were presented as rigid and unpleasant and nearly that many were presented as having unusually low intelligence. The only characters presented in passive roles were women, 13.6 percent, and an equal number were shown as social isolates. Men have a slightly higher percentage considered to be sickly. Once again, however, the major finding is that the majority of characters, both male and female, were not presented as having the undesirable traits measured in this study and found to apply in previous research.

\section{CONCLUSIONS}

Prior research has found the elderly and females to be significantly underrepresented in American television. Furthermore, when they were portrayed, older people and women often were depicted in negative, stereotypical ways. However, some social scientists have suggested that societal changes in recent years may have brought about a change in the way these people are presented. In fact, persons representing the television industry have stated that steps have been taken to eliminate sexist and ageist characterizations. The purpose of the present study was to ascertain whether changes have taken place in the way the elderly are portrayed.

The findings from this study indicate that older people continue to be underrepresented on prime-time television. Whereas people 65 and older make up 12.1 percent of the American population, only 3.3 percent of those shown on prime-time television are in this age group. Furthermore, a gender bias still exists within the elderly category. Older men are seen twice as often as elderly women. The continued lack of representation of older persons gives cause for concern. Kubey (1980) notes that the extent to which television serves as a reflection of attitudes toward the elderly and the extent it serves as a cause is unknown. It seems clear, however, that appearance on television connotes importance and status and that invisibility or absence represents lack of importance or insignificance. 
This study did not find as marked a distortion and negative images of the elderly as reported in previous research. Positive characterizations were noted more frequently than negative ones and the most frequently observed negative attribute, rigidity, was observed for only 17.2 percent of the cases. Since there is no reason to believe that previous studies were inaccurate, this suggests that negative images are being replaced by more positive portrayals. On the other hand, while positive characteristics did outweigh the negative, the investigators found few examples of elderly persons presented in realistic situations with multi-dimensional characterization. To some extent, it appears that negative images are being replaced by flat, one-dimensional, neutral characterizations. Nevertheless, there is room for cautious optimism in this regard in that older persons apparently are less likely than in the past to be depicted in a negative, stereotypical manner.

The pattern of the differences between men and women in the ways they were characterized suggests that traditional gender roles that favor males continue to be depicted on prime-time television. Males have higher percentages than females on six of the nine positive characteristics measured. Females have higher percentages than males on six of the seven negative characteristics that showed a gender difference. If this does show a continuation of traditional gender roles and evaluations, however, it may be only a vestige, a disappearing reflection, because, whereas the pattern shows a significant gender difference, none of the specific gender differences are statistically significant.

The study had one serendipitous finding that should be examined through further research. As shown in Table 1, by far the largest ratio of male to female characters was among those defined as middle-aged. We also found that older middle-aged men, ages 50 to 64, appeared in leading roles in 17 programs, e.g., Matlock, The Equalizer, The Oldest Rookie, Buck James. The starring roles for males in this age group included lawyers, doctors, detectives, crime fighters and writers. Also, many leading men in situation comedies appeared to be in their 50s, e.g., Bill Cosby, Bob Newhart, Howard Hessman. We do not know if there has been an increase in the proportion of leading male characters who are in their older middleaged years, but it would be consistent with the aging of the Ameri- 
can population if true and could signal the beginning of the end of the nation's strong orientation toward and adoration of youth. Interestingly, however, the girlfriends or wives of the older middle-aged men are approximately 10 to 15 years younger. This, of course, is consistent with the traditional practice of men dating and marrying women younger than themselves, but some of the discrepancies on television test the limits of credibility. One disturbing implication is that this age disparity, along with the relative absence of middle-age women on television, perpetuates the idea that women must remain youthful in appearance while men are allowed to show signs of aging. Bell (1970, p. 75) observes that what status women have is based on their sexuality and that inevitable physical symptoms of aging make women sexually unattractive much earlier than men but that males are valued more "in terms of personality, intelligence, and earning power than physical appearance." Davis and Davis (1985) are concerned about the impact upon individuals and relationships. They contend that the depiction of older females on television places women in the disadvantaged position of striving to remain youthful and that men are conditioned to see older women as less desirable and the aging process as something to be avoided. Thus, men may "have difficulty being supportive of the unavoidable consequences of aging in their mates, and in themselves" (Davis and Davis, 1985, p. 48).

One further point should be mentioned in conclusion. Since this study was designed to examine television's portrayal of the elderly, the finding of a preponderance of older, middle-age men in leading roles in contrast to a relative lack of appearance of middle-age women represents a case of serendipity. Given the possibly important implications of this, both with respect to changing attitudes toward youth and differential evaluations of aging for males and females, this would seem to be an area deserving further study.

In summary, this study illustrates that the older person on prime time television is being portrayed as more active, pleasant and more involved than in the past. It offers some support for Tibbets' (1979) optimistic assertion that negative stereotypes are being replaced by more positive perceptions. However, the findings also indicate that ageism continues to exist in terms of both underrepresentation and characterization. Perhaps the most surprising finding is the prepon- 
derance of middle-age men in focal roles in contrast to a relative lack of middle-age women. Most disturbing is the perpetuation of the idea that women must remain youthful in appearance while men are allowed to show signs of aging.

\section{NOTE}

1. Passuth and Cook (1985) contend that television has little or no effect on attitudes and knowledge about elderly people. The present study cannot speak to this issue since it examine the way in which the elderly are presented, not with the influence of that presentation.

\section{REFERENCES}

Ansello, E. F. (1978). Broadcast images: The older woman in television. Paper presented at the meeting of the Gerontological Society, Dallas, TX.

Aronoff, C. (1974). Old age in prime time. Journal of Communication, 24, 86-7. Austin, D. R. (1985). Attitudes toward old age: A hierarchical study. The Gerontologist, 25, 431-34.

Bell, I. P. (1970). The double standard: Age. Trans-Action November-December, 75-80.

Bergman, B. R. (1986). The economic emergence of women. New York: Basic Books.

Berg, B. (1989). Qualitative research methods for the social sciences. Boston: Allyn and Bacon.

Bishop, J. M. \& Krause, D. R. (1984). Depictions of aging and old age on Saturday morning television. The Gerontologist, 24, 91-4.

Butler, R. N. (1975). Why survive? Being old in America. New York: Harper \& Row.

Carmichael, C. W. (1976). Communication and gerontology: interfacing disciplines. Journal of the Westem Communication Association, 40, 121-29.

Cassata, M. B., Anderson, P. A., \& Skill, T. D. (1980). The older adult in daytime serial drama. Joumal of Communication, 30, 48-9.

Comstock, G., Chaffee, S., Katzman, N., McCombs, M., \& Roberts, D. (1978). Television and human behavior. New York: Columbia University Press.

Dail, P. (1988). Prime-time television portrayals of older adults in the context of family life. The Gerontologist, 28, 700-706.

Davis, R. H. \& Davis, J. J. (1985). T. V. 's image of the elderly: a practical guide for change. Boston: Lexington Books.

Downs, C. A. \& Harrison, S. K. (1985). Embarrassing age spots or just plain ugly? Physical attractiveness stereotyping as an instrument of sexism on American television commercials. Sex Roles, 13, 9-19. 
Elliot, J. (1984). The daytime television drama portrayal of older adults. The Gerontologist, 24, 628-33.

Gerbner, G., Gross, L., Signorielli, N., \& Morgan, M. (1980). Aging with television: Images on television drama and conceptions of social reality. Joumal of Communication, 30, 37-47.

Greenburg, B. S., Korzenny, F., \& Atkin, C. K. (1979). The portrayal of the aging: Trends on commercial television. Research on Aging, 17, 319-34.

Harris, A. J. \& Feinberg, J. F. (1977). Televison and aging: Is what you see what you get? The Gerontologist, 17, 464-68.

Harris, L. (1975). The myth and reality of aging in America. Washington, D.C.: National Council on Aging.

Holtzman, J. \& Akiyama, H. (1985). What children see: The aged on television in Japan and the United States. The Gerontologist, 25, 62-67.

Kubey, R. W. (1980). Television and aging: Past, present, and future. The Gerontologist, 20, 16-35.

Northcott, H. C. (1975). Too young, too old - Age in the world of television. The Gerontologist, 15, 184-86.

Passuth, P. M. \& Cook, F. L. (1985). Effects of television viewing on knowledge and attitudes about older adults: A critical reexamination. The Gerontologist, $25,69.77$.

Peterson, M. (1973). The visibility and image of old people on television. Journalism Quarterly, 50, 569-73.

Senter, S. (1982). Women at work. New York: Perigee.

Signorielli, N. \& Gerbner, G. (1978). The image of the elderly in prime-time television drama. Generations, 3, 10-11.

Silverstein, B., Perdue, L., Peterson, B., \& Kelly, E. (1986). The role of the mass media in promoting a thin standard of bodily attractiveness for women. Sex Roles, 14, 519-32.

Tibbitts, C. (1979). Can we invalidate negative stereotypes in aging? The Gerontologist, 19, 10-20. 